\title{
Assessment of the effect of intravitreal triamcinolone acetonide on the chorioretinal and vitreous inflammatory reaction to cryotherapy in rabbits
}

\author{
Avaliação do efeito da injeção intravítrea de \\ triancionolonaacetonida sobre a reação inflamatória \\ coriorretiniana e vítrea à crioterapia em coelhos
}

Eugênio Santana de Figueirêdo', Fabio Endo Hirata ${ }^{1}$, Leandro Luiz Lopes Freitas², Valdir Balarin Silva ${ }^{3}$

\begin{abstract}
Purpose: To evaluate the inflammatory response in the choroid, retina and vitreous in rabbit eyes underwent cryotherapy followed by intravitreal triamcinolone acetonide and to compare with those underwent cryotherapy followed by intravitreal injection of saline solution. Methods: This is a prospective case-control study. Surgical procedures were performed in eleven rabbits. Two animals were excluded because they did not complete the postoperative period or had intraoperative or postoperative complications. All rabbits underwent superior temporal peritomy and transscleralcryotherapy in both eyes. After cryotherapy, animals received intravitreal injection of triamcinolone acetonide in one eye and saline solution in the fellow eye. Animals were sacrificed seven days after the procedure and their eyes were enucleated. Histological sections of eyeballs were prepared and the vitreous humor was aspirated. The count of inflammatory cells was performed by light microscopy. Results: Histological sections of both eyes of nine rabbits were analyzed. Inflammatory cells were found only in the choroid. There was no statistically significant difference in the number of inflammatory cells between the two groups, regardless of cell type analyzed. Conclusion: This study showed no statistically significant difference between the use or absence of intravitreal triamcinolone acetonide in the inflammatory response to cryotherapy in rabbit eyes. Studies with larger samples are needed to confirm the trend of this paper.
\end{abstract}

Keywords: Vitreous body/citology; Cryotherapy; Histology; Inflammation; Triamcinolone acetonide; Rabbits

\begin{abstract}
Resumo
Objetivo: Avaliar a resposta inflamatória em coróide, retina e vítreo nos olhos de coelhos submetidos à crioterapia seguida de injeção intravítrea de triancinolona acetonida e comparar com os olhos de coelhos que foram submetidos à crioterapia seguida de injeção intravítrea de solução salina. Métodos: Trata-se de um estudo prospectivo caso-controle. Foram realizados procedimentos cirúrgicos em 11 coelhos albinos, sendo excluídos os animais que não completaram o pós-operatório ou apresentaram complicações intra ou pós-operatórias. Todos os coelhos foram submetidos à peritomia temporal superior e aplicação de crioterapia transescleral em ambos os olhos. No final de cada procedimento, os animais receberam injeção intravítrea de triancinolona acetonida em um olho e de solução salina no olho contralateral. Após 7 dias de pós-operatório, os animais foram sacrificados e tiveram seus olhos enucleados. O humor vítreo desses olhos foi aspirado, e realizou-se a confecção de cortes histológicos dos globos oculares. Foi feita a contagem das células inflamatórias desses materiais em microscópio óptico. Resultados: Foram analisados cortes histológicos dos olhos de 9 coelhos. Foram encontradas células inflamatórias apenas na coróide em todos os olhos. Não houve diferença estatisticamente significante no número de células inflamatórias entre os dois grupos estudados, independente do tipo celular analisado. Conclusão: $\mathrm{O}$ artigo em questão não demonstrou influência da triancinolona acetonida intravítrea na resposta inflamatória à crioterapia em coelhos. São necessários estudos com amostras maiores para confirmar a tendência deste trabalho.
\end{abstract}

Descritores: Corpo vítreo/citologia; Crioterapia; Inflamação; Triancinolona acetonida; Coelhos

1Post-graduated Program, Department of Ophthalmology - Faculty of Medical, Universidade Estadual de Campinas (UNICAMP) - Campinas (SP), Brazil; ${ }^{2}$ Universidade Estadual de Campinas (UNICAMP) - Campinas (SP), Brazil;

${ }^{3}$ Universidade Estadual de Campinas (UNICAMP) - Campinas (SP), Brazil.

Interest conflict - None

Recebido para publicação em 27/8/2011 - Aceito para publicação em 7/3/2012

Rev Bras Oftalmol. 2012; 71 (5): 309-12 


\section{INTRODUCTION}

$\mathbf{0}$ ver the years, cryotherapy has been used as an adjunct to surgical treatment of retinal detachment. It creates adherence between the detached layers in the retinal tears, contributing to the success of the procedure ${ }^{(1)}$. However, there may be increased inflammatory response in the vitreous, leading to formation of vitreous membranes and proliferative vitreoretinopathy (PVR), which can be potentially detrimental to surgery outcome ${ }^{(2)}$. Therefore, the use of anti-inflammatory substances after cryotherapy, such as steroids, has been proposed in order to reduce inflammatory response and the likelihood of breakdown of the blood-retinal barrier ${ }^{(2-5)}$.

Triamcinolone acetonide is a long-term steroid commonly used for disorders of the vitreous, retina and choroid due to its anti-inflammatory and anti-angiogenic properties. In ophthalmic practice, this drug is used in its injectable form. The most frequent dosages are $4 \mathrm{mg}$ and $20 \mathrm{mg}^{(6)}$.

The objective of the present study is to assess the number of choroidal, retinal and vitreous inflammatory cells (lymphocytes, plasmocytes, eosinophiles, neutrophiles and macrophages) in the eyes of rabbits that underwent cryotherapy followed by intravitreal triamcinolone acetonide injection and compare the results with eyes submitted to cryotherapy followed by saline solution injection.

\section{Methods}

This was a prospective, case-control study. Research protocol was approved by the Animal Experimentation Ethics Committee (Comissão de Éticana ExperimentaçãoAnimal) at UNICAMP. Surgical procedures were conducted in 11 (eleven) New Zealand white rabbits of the same strain, whose weigh ranged from 2.5 to 3.0 kilograms $(\mathrm{kg})$. Animals which did not survive postoperative period or that had intra or postoperative complications were excluded from the study. Surgical procedures were conducted at the Experimental Surgical Center at Unicamp (Núcleo de Cirurgia Experimental da UNICAMP).

The animals were anesthetized with a combination of intramuscular ketamine (Ketalar®, Pfizer, Guarulhos, Brazil) [60 milligrams $(\mathrm{mg}) / \mathrm{kg}$ ] and xilazine (Anasedan $®$, CevaSaúde Animal Ltda., Paulínia, Brazil) $(10 \mathrm{mg} / \mathrm{kg})$. Both eyes underwent superotemporal quadrant peritomy followed by 20 seconds of cryotherapy using a Cryogenic Unit (Cryofast ${ }^{\circledR}$, Alimed Tec, Sao Paulo, Brazil) with a 3.0 millimeters $(\mathrm{mm})$ tip, with a carbon dioxide cylinder in two adjacent areas located at the equator of this quadrant. The retina was not visualized during cryotherapy. After cryotherapy, each eye received an intravitreal injection, $2.0 \mathrm{~mm}$ from limbus (pars ciliata), on the same quadrant. One of the eyes received 0.1 milliliters $(\mathrm{ml})$ triamcinolone acetonide $40 \mathrm{mg} / \mathrm{ml}$ without preservative (Ophthalmos, Sao Paulo, Brazil) and the fellow eye received $0.1 \mathrm{ml}$ physiologic saline solution at $0.9 \%$ (Farmace, Barbalha, Brazil). The eyes which would receive each product were previously sorted and randomly chosen. A $26 \frac{1}{2}$ gauge needle was used, and the injection was long enough to inject the substances. A previous anterior chamber paracentesis was not performed. After injection, the puncture site was compressed with a cotton swab. There was no observed drug reflux. At the end of each procedure, the previously dissected conjunctiva was sutured with one stitch of 8-0 silk (Ethicon, Sao Paulo, Brazil).

The animals were kept alive with adequate postoperative care for seven days: 01 drop of ofloxacin at $0.3 \%$ (Oflox ${ }^{\circledR}$, Allergan, Sao Paulo, Brazil) every four hours; 01 drop of tropicamide (Mydriacyl@, Alcon, Sao Paulo, Brazil) at 1\%, every eight hours, and 01 drop $/ \mathrm{kg}$ of sodium dipirone $500 \mathrm{mg} / \mathrm{ml}$ (Novalgina ${ }^{\circledR}$, Sanofi-Aventis, Suzano, Brazil) orally, every six hours. After this period, the rabbits received a lethal dose of intramuscular ketamine and xilazine (three times the anesthetic dose) and their eyes were removed and sent to the Pathologic Anatomy Department (Departamento de Anatomia Patológica) / UNICAMP, so that the inflammatory cells could be counted, in a $10 \%$ formaldehyde solution.

After fixation, the vitreous was aspirated with a $26 \frac{1}{2}$ gauge needle. The material resulting from the aspiration was adequately processed in a cytocentrifuge, and sediments were dyed in hematoxiline-eosine (HE). After aspiration, each ocular globe was cut in half, reaching the cornea, iris, crystalline and optic nerve. The two halves were embedded in paraffin. A histological cut of $6 \mu \mathrm{m}$ was made in each block and dyed with HE.

The examination was conducted with an ordinary coobservation optical microscope, with two simultaneous observers. In histological sections, an area in the field of higher magnification $(400 \mathrm{X})$ with greater quantity of inflammatory cells at the retina and choroid (hot spot area) was localized. Based on this area, another nine adjacent consecutive areas were assessed. The inflammatory cells (lymphocytes-like, plasmocytes-like, eosinophiles-like, neutrophiles-like and macrophages-like) were counted and identified according to their morphological characteristics. Immunohistochemical analysis was not performed. The final results were obtained by summing up all ten areas. In the analysis of sediments, 10 consecutive fields were counted at the outer layer of the centrifuged material, in immersion magnification (1000X), and the result consisted of the sum of fields with the identification of cell types present.

Statistical analysis was performed at Statistics Research Board of the College of Medical Sciences (Câmara de Pequisa Estatística da Faculdade de CiênciasMédicas) / UNICAMP. In order to compare the variables of the study, treatment and placebo, a Wilcoxon test was performed on the samples listed. The significance level adopted for such statistic tests was 5\%.

\section{ResULTS}

Histological sections of the eyes of 9 (nine) rabbits were analyzed. One rabbit was excluded when presented with clinical signs of infectious endophthalmitis in one eye. Another animal was excluded due to secondary complications related to anesthesia, not having completed the postoperative period of seven days.

No inflammatory cells were seen in the histological sections of the retina and vitreous aspirate in the two groups of eyes studied. The cells counted were found solely in choroid (Figures

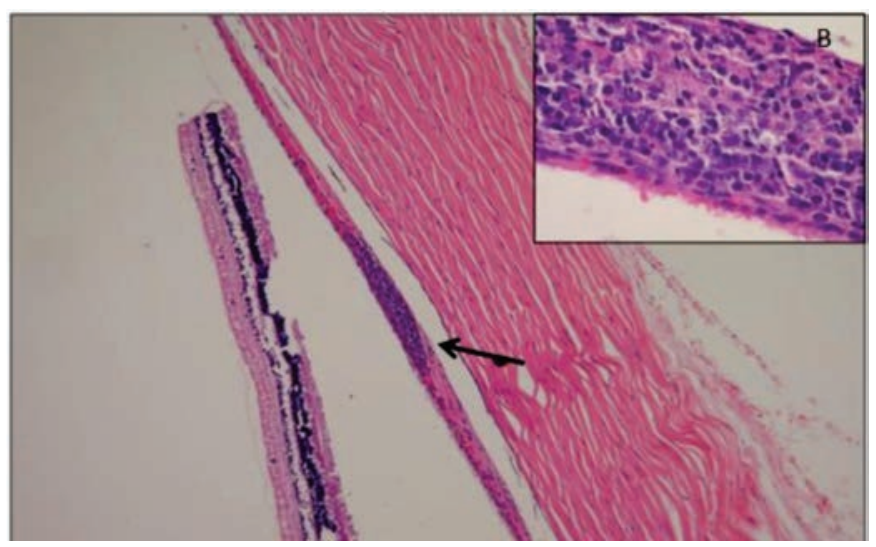

Figure 1: (A) Panoramic view of histological section of the eye treated with triamcinolone acetonide showing, from right to left: sclera, choroid with lymphoid aggregate (arrow) and retina; (B) detail of choroidal lymphoid aggregate with a predominance of lymphocytes-like 


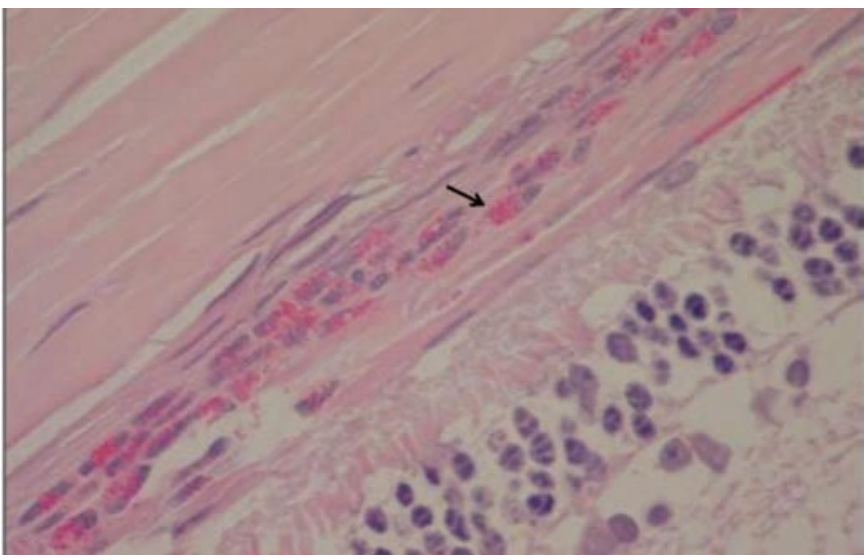

Figure 2: Choroidal infiltrate with numerous eosinophiles-like (arrow) in an eye treated with saline solution

1,2 and 3). Alterations such as metaplasia or hypertrophy of retinal cells were not found in any of the eyes evaluated.

Average number of eosinophile-like was lower in the group using triamcinolone acetonide than in the placebo group (42.6 x 51.0, $\mathrm{p}=0,9453)$. However, average counts of the other cells were greater for the group under treatment. There was no statistic significance in the comparison of such

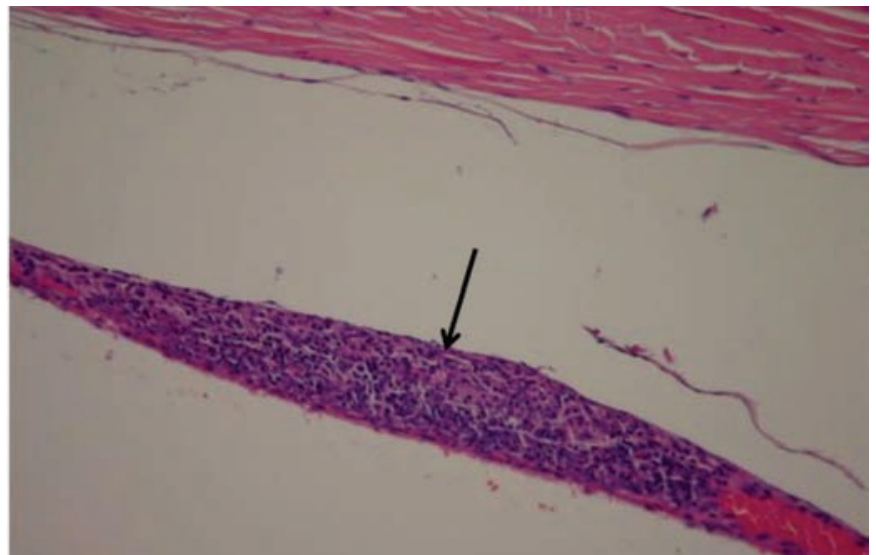

Figure 3: Choroidal aggregate with lymphocytes-like (arrow) in an eye treated with saline solution

values (Table 1).

Rabbit number 9 displayed a considerable increase in lymphocytes-like on both eyes (321 lymphocytes-like/field in the eye treated with triamcinolone acetonide and 250 lymphocyteslike/field in the fellow eye). Some of the eyes studied had increased numbers of eosinophiles-like regardless of receiving triamcinolone acetonide treatment(Table 2).

Table 1

Descriptive analysis and comparison of the types of inflammatory cells present in the choroid of the eyes examined

\begin{tabular}{lrrrrrrr}
\hline \multicolumn{1}{c}{ Cell } & \multicolumn{2}{c}{ Average } & \multicolumn{2}{c}{ Standard deviation } & \multicolumn{2}{c}{ Median } & \multicolumn{2}{c}{ p - value* } \\
& TE & \multicolumn{1}{c}{ PE } & \multicolumn{1}{c}{ TE } & \multicolumn{1}{c}{ PE } & \multicolumn{1}{c}{ TE } & \multicolumn{1}{c}{ PE } & 0.3008 \\
\hline Lymphocytes-like & 70.9 & 51.9 & 103.9 & 79.4 & 20.0 & 18.0 & 0.1875 \\
Plasmocytes-like & 1.4 & 0.4 & 1.5 & 0.7 & 2.0 & 0.0 & 1.0000 \\
Neutrophiles-like & 1.2 & 0.7 & 2.9 & 0.7 & 0.0 & 1.0 & - \\
Macrophages-like & 0.0 & 1.1 & 0.0 & 3.3 & 0.0 & 0.0 & 0.9453 \\
Eosinophiles-like & 42.6 & 51.0 & 84.4 & 90.2 & 3.0 & 6.0 & 0.9453 \\
Total cells 116.1 & 116.1 & 105.1 & 159.5 & 119.2 & 20.0 & 26.0 & \\
\hline
\end{tabular}

(*)p-value for paired Wilcoxon Test (null hypothesis: difference median $=0$ );

$\mathrm{TE}$ - Eye receiving intravitreal triamcinolone; PE - Eye receiving intravitreal placebo

Table 2

Comparison of number of inflammatory cells in the choroid of the eyes examined

\begin{tabular}{|c|c|c|c|c|c|c|c|c|c|c|c|c|}
\hline \multirow[t]{2}{*}{ Rabbit } & \multicolumn{2}{|c|}{ Lymphocytes-like } & \multicolumn{2}{|c|}{ Plasmocytes-like } & \multicolumn{2}{|c|}{ Neutrophiles-like } & \multicolumn{2}{|c|}{ Macrophages-like } & \multicolumn{2}{|c|}{ Eosinophiles-like } & \multicolumn{2}{|c|}{ Total cells } \\
\hline & TE & PE & TE & PE & TE & PE & TE & PE & TE & PE & TE & PE \\
\hline 1 & 10 & 15 & 0 & 0 & 0 & 1 & 0 & 10 & 2 & 0 & 12 & 26 \\
\hline 3 & 149 & 20 & 2 & 2 & 9 & 1 & 0 & 0 & 3 & 242 & 163 & 265 \\
\hline 4 & 5 & 13 & 0 & 1 & 0 & 1 & 0 & 0 & 3 & 11 & 8 & 26 \\
\hline 5 & 64 & 39 & 2 & 1 & 1 & 0 & 0 & 0 & 241 & 24 & 308 & 64 \\
\hline 7 & 33 & 97 & 4 & 0 & 1 & 1 & 0 & 0 & 10 & 171 & 48 & 269 \\
\hline 8 & 16 & 10 & 2 & 0 & 0 & 0 & 0 & 0 & 1 & 1 & 19 & 11 \\
\hline 9 & 321 & 250 & 3 & 0 & 0 & 0 & 0 & 0 & 123 & 4 & 447 & 254 \\
\hline
\end{tabular}

TE - Eye receiving intravitreal triamcinolone; PE - Eye receiving intravitreal placebo 


\section{Discussion}

Histological studies of eyes submitted to cryotherapy have revealed the occurrence of cellular reactions in the retina after four weeks of application, such as proliferation and metaplasia of pigmented epithelium cells of the retina, hypertrophy of Müller ells, and proliferation of astrocytes. Inflammatory cells were not registered ${ }^{(7)}$. Such alterations were not found in the retina of the eyes examined in this study, probably due to the fact that the analyses were performed only seven days after cryotherapy.

Cryotherapy causes breakdown of the blood-retinal barrier ${ }^{(4,8,9)}$. The literature does not indicate that this could make the presence of inflammatory cells in the vitreous humor more likely. Nonetheless, the absence of inflammatory cells in the vitreous of the eyes examined may be caused by limitations in the method of collection and/or analysis of the material.

A previous report ${ }^{(10)}$, that evaluated the influence of cryotherapy and diode laser photocoagulation on the growth of rabbit eyes, found areas of intraretinal peripheral macrocystoid edema and chronic inflammatory reaction. However, the authors performed between 15-20 cryo burns in each eye, with evaluation of histological sections after 10 weeks of follow up. In this study, only two cryo burns were performed and histological analysis was done earlier. This may explain the absence of these histological changes in our study.

An experimental research ${ }^{(5)}$ showed that intravitreal triamcinolone acetonide was able to reduce the develop-ment of PVR after intravitreal injection of macrophages in rabbit eyes, probably by the action of the drug in the inflammatory stage of PVR. In another study with rabbits ${ }^{(2)}$, the authors found a decrease in retinal adhesion caused by cryotherapy in animals undergoing subconjunctival injection of triamcinolone acetonide $20 \mathrm{mg}$ compared to those subjected to saline injection. This is a likely consequence of the anti-inflammatory properties of this drug.

In some of the eyes analyzed, large choroidal concentrations of eosinophiles-like and lymphocytes-like were found, without any apparent relation to the treatment, or unrelated to the triamcinolone acetonide. Because there are no consistent data in the literature, the possibility that this might have occurred as an extreme reaction to cryotherapy may not be dismissed. However, the hematological conditions of the animals were not analyzed, which could have indicated that the increase in the number of cells resulted from some other concurrent clinical condition.

The present study has not shown statistically significant difference, regarding the number of inflammatory cells in the retina, vitreous or choroid between the two groups. This may be due to the size of the sample analyzed. However, due to the high standard deviation values for the average cell count studied, sample calculations have shown that increasing the number of eyes analyzed would not be statistically feasible.

\section{Conclusion}

The inflammatory response in the retina, choroid and vitreous in rabbit eyes undergoing transscleralcryotherapy does not appear to be influenced by the use of intravitreal triamcinolone acetonide. However, this study has a small sample and results highly variable, preventing a more accurate conclusion. Further studies are needed to confirm whether the use of this drug helps to decrease the number of inflammatory cells in the posterior segment of eyes that underwent cryotherapy.

\section{RefERENCES}

1. Farah ME. Descolamento regmatogênico da retina. In: Lavinsky J, organizador. Doenças prevalentes da retina e vítreo. Rio de Janeiro: Cultura Médica; 2002.

2. Flindall RJ, Leonard BC. The effect of corticosteroids on the retinal cryoadhesion. Can J Ophthalmol. 1973;8(4):566-8.

3. Chandler DB, Hida T, Sheta S, Proia AD, Machemer R. Improvement in efficacy of corticosteroid therapy in an animal model of proliferative vitreoretinopathy by pretreatment. Graefes Arch Clin Exp Ophthalmol. 1987;225(4):259-65.

4. Lee JH, Kim SJ, Chung H. The effect of subtenon injection of methylprednisolone acetate on the breakdown of blood retinal barrier after cryotherapy. Korean J Ophthalmol. 1995;9(1):1-6.

5. Liang HC, Hui YN, Cai YS. [Triamcinolone acetonide in the prevention of experimental proliferative vitreoretinopathy]. Zhonghua Yan KeZaZhi. 1994;30(2):122-4. Chinese.

6. Jermak CM, Dellacroce JT, Heffez J, Peyman GA. Triamcinolone acetonide in ocular therapeutics. SurvOphthalmol. 2007;52(5): 503-22. Comment in SurvOphthalmol. 2008;53(2):184; author reply 184 .

7. Laqua H, Machemer R. Repair and adhesion mechanisms of the cryotherapy lesion in experimental retinal detachment. Am J Ophthalmol. 1976;81(6):833-46.

8. Jaccoma EH, Conway BP, Campochiaro PA. Cryotherapy causes extensive breakdown of the blood-retinal barrier. A comparison with argon laser photocoagulation. Arch Ophthalmol. 1985;103 (11):1728-30.

9. Steel DH, West J, Campbell WG. A randomized controlled study of the use of transscleral diode laser and cryotherapy in the management of rhegmatogenous retinal detachment. Retina. 2000;20(4):346-57.

10. Axer Siegel R, Bourla D, Kremer I, Weinberger D, Snir M. Effect of peripheral retinal ablation with cryotherapy versus diode laser photocoagulation on axial length in the growing rabbit eye. Br J Ophthalmol. 2006;90(4):491-5.

\author{
Autor correspondente: \\ Eugênio Santana de Figueirêdo \\ Rua Eleutério Rodrigues, n 201/22 - Vila Nova \\ CEP 13073-066 - Campinas - (SP), Brazil \\ Fax.: (88) 3512-1489 \\ E-mail: eugsantana@ig.com.br
}

